\title{
The globalising effect of commercialisation and commodification in African theological education
}

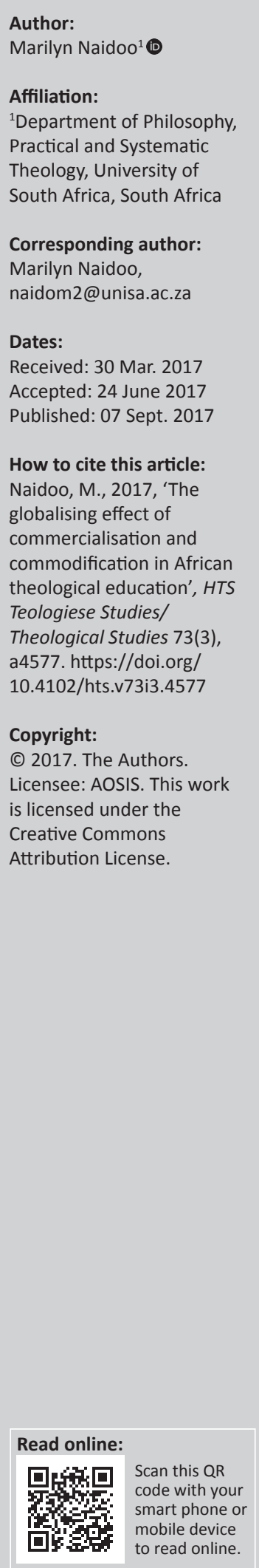

The reality of globalisation is that it has knitted the world into a single time and place and has introduced the dominant force of consumerism. In adopting this framework, it has frayed the moral fabric of theological education and has short changed students who are configured as consumers to please rather than characters to build. While the demographic centre of faith has shifted southward, its ways of thinking and engaging culture have not yet caught up with that shift. Global interconnectedness and the globalisation of knowledge together with homogenisation forces have shaped African theological education to the extent that it has absorbed the almost irreversible traits of the West. This paper highlights how transnational cultural forms have profoundly impacted the production of theological education and will attempt a response to the homogenising forces by the focus of African identity.

\section{Introduction}

The globalisation discourse provides fresh ways to interpret Christian self-understanding amid global transformations that are taking place in the third millennium. Several interpretive typologies have dominated the discussion, among which is the southward shift and the various post-templates, for example, post-colonial, post-denomination, post-missionary and postChristendom. The idea of the 'global village' provides a new way of conceptualising the changing tides of religion and specifically in Christianity. So much so that Philip Jenkins (2002) has declared that the world is witnessing the making of the next Christendom and the coming of global Christianity.

Paul Rajashekar reminds us that the church has played a major role in the process of globalisation, 'both as an agent in and as a product through its missionary engagement around the world' (2015:6). This has resulted in, according to Joel Carpenter, 'the homogenization of culture worldwide, the destruction of indigenous local traits and gifts, the triumph of consumerist values and commodification of the values and outlook of daily life' (2008:173). The impact of globalisation on churches and theological institutions has been powerful in such a manner that whatever happens in one part of the globe is immediately known in another part. Warner (2011:120) in his chapter, How Congregations Are Becoming Customers, notes that 'the religious market is shifting towards the pragmatic, experiential, de-traditional, post-denominational and therapeutic' where in a diverse market place, the 'preeminent authority of consumer choice' prevails. Social science scholars of religion and theologians alike have reflected on these effects of commercialising and commodifying forces on the sacred (Hellas et al. 2005; Hueser 2015; Miller 2003).

An important resultant factor of globalization has been growth and the critical need for trained leaders. The complexity of the exponential church growth is most perceptible in emergent forms of ministerial formation - unaccredited Bible schools, online and distance education, short-term courses offered by well-meaning global partners, outright sale of certificates, traditional denominational seminaries, public universities and a host of other strategies (Jenkins 2002; Werner 2009). Also, in spite of the widening digital divide in the continent, there has been a surge of interest in new technologies that has caused an eager population to become further connected, though still to varying degrees (Naidoo 2012:2). Many private theological institutions in South Africa have now moved to distance (online and correspondence) education, seen as a solution to the challenge of financial viability. What is clear is that the growth of the church in Africa generally has become so enormous (Jenkins 2002; Johnson \& Ross 2009; Kalu 2006:233) that the need for leaders far outstrips the ability of Bible and theological institutions, seminaries and correspondence programmes to supply them. Spurred on by the 'third wave' of tremendous growth mostly from the neo-Pentecostal and Independent churches (Johnson \& Ross 2009:102), has resulted in changes in the very contours of historic Christianity. Together with the prosperity gospel and the popularity 
it has achieved (Hueser 2015:5; PEW Forum on Religion and Public Life 2010), the emphasis on health, wealth, promotion and power in the gospel has had implications for how churches train their leadership.

According to Kalu (2006:234), 'growth has traumatised theological education in Africa', where church leaders are more interested in certificates, especially from foreign countries, and obtain degrees by taking correspondence courses from American or South Asian institutions. Or as Kalu (2006:236) says: 'others simply buy certificates from fake operators or groups of Americans travel through the developing world ordaining bishops and granting degrees as a way of building a worldwide network'. Kalu (2006:237) asks: 'who can control all these institutions and ensure an accredited performance, a liberating curriculum and adequate infrastructure?'.

Globalisation has resulted in uncertainty in theological education, precipitated and prompted by a number of factors as Van der Water states (2005):

- the processes of rationalisation within educational and ecclesiastical institutions

- the competing and sometimes adversarial interests of liberal, radical and conservative theological establishments

- the redirecting of financial resources away from theological education to other disciplines under governments that have become secular states. (p. 203)

Dietrich Werner (2009:5) reiterates that commercialised Christian religion, shallow 'prosperity-Gospel' variations and 'cheap' theological training and courses have an inroad and outreach now, in all sectors and layers of churches in Africa.

Within theological education it is important to understand how transnational cultural forms are set in motion and domesticated, investigating the way in which local cultural lenses refract the light in global cultural processes. Many scholars have explored the contested religious expression of homogeneity and sameness brought about by globalisation (Anderson 2004; Carpenter 2008; Kalu 2008a). Homogeneity breeds 'intellectual and political myopia and perpetuates an existing education and symbolic ordering of the dominant culture' (Kalu 2008a:5). What reflects the world of the dominant group is considered normative, while what is different is considered as peripheral and of less value. The risk is that it prevents Africans from reflecting on their experience of the gospel message. Nigerian theologian Justin Ukpong (1995) reminds us that:

in the process of evangelisation each new culture with which Christianity comes into contact with, should be respected and given the chance to give its own expression to the Christian message. (p. 179)

This article acknowledges the homogenising forces of globalisation that have profoundly shaped theological education and discusses the impact of what appears to be happening in our context and possible ways to counteract these pervasive forces.

\section{The influence of higher education}

Higher education is one of the most obvious forms of globalisation with its worldwide imposition of Western modernising values and political and economic hegemony (Wallerstein 1974). Universities are portrayed as businesses offering knowledge packaged and branded in the form of teaching programmes for sale to interested clients. Bridges and Jonathan (2003:132) speak of the university that has become part of the instrumentalist culture of modernity, with its marketability, corporatisation and the commodification of education. In South Africa, for example, impacted by the marketisation of education, outcomes-based education was embedded with neo-liberalist undertones that especially emphasise competition and individualism. Hyug Baeg (in Waghid 2001:458) states that young democracies often feel compelled to accept neo-liberalist reform methodologies to expand their social, economic and political interests. Sandel reiterates that the reach of markets, and market-oriented thinking, into aspects of life traditionally governed by nonmarket norms is one of the most significant developments of our time' (2012:7).

More than a decade ago, Naomi Klein (1999:98) bemoaned the creeping consumerism within higher education, characterised by disengaged students who adopt a 'mall mentality' of casually 'cruising' curricular and co-curricular offerings. Bridges and Jonathan (2003) caution of how market principles to education can lead to a misrepresentation of the ontology of education:

... that education becomes a commodity and schools production lines, 'educated' students the products and teachers rewarded on the basis of their productivity. Such language, it is argued, systematically distorts our understanding of the nature of education ... it turns intrinsic values and essential moral and humanistic relations into instrumental ones. (p. 132)

With theological education, the entrepreneurial marketing of it, valuing the student in terms of what they can consume or produce and the supermarket of theological offerings brings into focus the commercialisation of theological education. The value of education is measured in terms of what can be produced or consumed and becomes crassly utilitarian. The corporatisation of universities means that academic disciplines, like theology, that are not immediately associated with marketability and career openings have come under pressure, as governments and students look to economic return as a measure of worth of a university programme.

In addition, education has become viewed and treated as a commodity to pick and choose and knowledge is viewed as a product. Conradie (2011:440) states that, 'given the overload of information, consumers have to adopt shallower forms of attention as a survival strategy ... leading to a reductionist understanding of knowledge'. The concern for theological education is that the exaggerated focus on 'knowledge', 
elevated to the status of sacred text, is to be transmitted, memorised and perhaps contemplated but not used (Overend 2007). This has resulted in a deep identity crisis not only for theologians but also for those involved in the human and social sciences, because now teaching is more about the production of knowledge. It is widely recognised that the focus in the curriculum is on the academisation of theological education with administrative and disciplinary silos (Farley 1984; Foster et al. 2006), when integration is what is really required. Commodification encourages catering to students, pleasing them by minimising challenges rather than equipping them to persevere in solving complex problems. What kind of preparation for life's challenges does an education provide that measures quality primarily by the degree of ease and convenience? Critics such as Ritzer (1996) observe that educational efficiency and quality are not coextensive. He analogises that fast foods might qualify as efficient, but they sacrifice nutritional value.

Besides this, the openness of the overcrowded curriculum itself aids the consumer mentality of our culture, reinforcing the character and values of students and frustrating the faculty's attempt to become involved in developing academic virtues or even ministerial formation (Naidoo 2015:12). Inducing people to care about each other or building a more respectful world simply does not occupy a necessary place in the value system of consumerist culture (Bauman 2008:23). Any sense of care attendant to consumerism has a purely instrumental role of caring about another's desires in order to satisfy them for some ulterior purpose, usually related to bolstering profits or reputation.

The secular character and the great pressure to secularise from within the academy are ongoing debates about the contested role of Christian theological education in a public university (Bird \& Smith 2009). According to David Bosch (1991:3-17), theology in the university tends towards the analytical, rational study of theology with little attention paid to spirituality and practice. Carpenter states that secularisation has come not from the head-on assault against supernaturalism but from the idea that 'empirical study is theologically neutral and universally beneficial' (2008:182). Like many university faculties, in denominational seminaries and bible colleges teaching and learning have an unmistakable academic cast that emphasises cognitive mastery of concepts and knowledge.

In spite of the developments towards a more holistic view of the individual learner in higher education, the dissonance between educational philosophy and theological understanding of the person and of formation would not seem to suggest that universities are an ideal partner in learning for ministry (Wilton 2007). Wilton states that 'structural partnerships are generally difficult because of divergent institutional aims' (2007:158). Higher education develops individuals within a market context of competition, while the Church seeks to form individuals to inhabit theological understandings, involving an understanding of personhood in the community (Overend 2007:140).
Within higher education, the development of accreditation has forced theological institutions to be accountable to government, the Church and the general public and this could result in greater effectiveness, which is positive. However, it raises the issue whether government bodies should be the only source for the assessment and accreditation of theological institutions. The Church will need to assist secular authorities and theological institutions in redefining the meaning of ministerial profession, the role of leadership and the educational formats that will serve the goals that emerge from these conversations (Dunsmuir \& McCoy 2015:38). Theological institutions also have to resolve the tension between the status of the institution as an autonomous authority with statutory recognition and an institution serving local Christian communities and churches (Moodie 2008:47). In South Africa, accreditation has resulted in the mushrooming of new theological training institutions, which has in turn created tensions between public and private providers of theological education as they compete for students (Naidoo 2015:12). The sudden growth in private theological education was partly because some traditions wanted to retain their specific identities and values, which they perceived to be under threat from secular bodies (Levy 2007:188)

More recently, the new entrepreneurial concept of education in the Christian university in the broader continent has emerged. These universities of evangelical and Pentecostal movements are a global phenomenon, 'a product of cultural transmission but everywhere transmuting into unique local forms and expressions' (Berger 1997:23). Privatisation, where 'economic decline and government fiscal crises have eroded the quality of higher education' has opened the door for the establishment of Christian universities (Carpenter 2008:172). Universities have always lived with the tensions between the disinterested pursuit of truth and the need to put knowledge to practical use, but in a new era of privatisation and globalisation, according to Carpenter, it is quite clear that 'usefulness is winning out' (2008:178). For example, Daystar University in Kenya, which follows a liberal arts approach, listed 1213 students for a Bachelor's degree programme in 1997. However, 1094 of its students were enrolled in one of the three programmes of commerce, communication and community development (Kalu 2006:236). According to Carpenter, 'the para-church agency revolution, which has transformed North American Christianity, is now making a major impact in Africa' (2008:170). However, it is difficult to see how these universities will sustain a Christian identity and mission considering the narrowly focused curricular tracks (Carpenter 2008:181) and, as Kalu expresses (2006:237), there is no clear line between theological and developmental agendas or whether they could be considered as centres of Christian thought and scientific scholarship.

Another development has been the internationalisation of theological education; a dialogue about the relevance of Western theory and practice in non-Western contexts. This trend refers to the growth of international students and faculty and extends well beyond the mobility of people to the 
movement of institutions. Theological education is now being exported from one country to another, particularly from the United States. As McKinney states: 'extension centres, branch campuses, franchising operations, and various other "transnational" higher education arrangements have become commonplace in Africa' (2003:6). In addition, the demand for flexibility of delivery has also led to another form of internationalisation, characterised by moving content, knowledge and courseware. Distance education and the expansion of the Internet have opened the way for the distribution of a 'virtual higher education'. It has freed students from the constraints of time and space, but it has created a new set of challenges in terms of ministerial formation (Naidoo 2012:4). In addition, ethical internationalisation (Dyrness 2014:1) is always questioned when one considers the rapid spread of evangelical or Pentecostal theological education, which reflects the lack of un-contextualised teaching material and curriculum plans. As Balia and Kim state (2010):

While this proliferation reflects a genuine desire for access to theological education, the rapid growth and commercialisation of theological education has led to negative side-effects. Many of these new institutions offer only light or 'fast-food' style education; no libraries, no developed curriculum and no consistent educational framework. They may also have no developed relationships with the indigenous church which exists in their context or connections with the established associations of theological education. This fragmentation, lack of cooperative relationships, common standards and the general lack of integration in the theological education landscape in some regions has reached unprecedented levels. (p. 163)

This has resulted in rapid church growth in theological education in the South; however, much of the theological reflection remains captive to a western model of theologising: foreign theological content, methodology and languages. Whether the theology taught in institutions is Christian dogmatics or constructive theologies, it invariably focuses on Euro-Western formulations of faith and philosophical thought Walls (2000:1). The dependence on the West is still widespread as evidenced in the strength of the missionary influence in terms of numbers, resources, expertise and power (Glifford 1998:17). Anderson states that (2004:8) 'Pentecostal and Charismatic churches are clones of western forms of theologizing and new initiatives in providing relevant theological education for third-world contexts are very few and far between'.

\section{What is at stake for theological education?}

Any discussion of theological education must take into account the rapid transformation of the world in the past several years. Here it is important to note that consumption and commodification are complex historical and cultural process. Bellah (1970:72) reminds us more than three decades ago that 'it has been impossible for religion to remain entirely indifferent to modernization'. In the words of Ward (2006:184), 'what we believe and the practices that produce, reinforce, and modify that believing are historically and culturally embedded'. A critical portrayal of commercialising is premised on the view that consumer culture negatively changes one's relationship to religious beliefs and practices (Moore 1994:34). It ruins and is harmful because money and profit run against the foundation of the faith and shows the signs of its growing worldliness and of market domination. Thus, it is counterproductive to Christianity, which is built around the aura of sacredness and timeless teachings and preaches against greed and vices rooted in desire, illusion and material madness.

However, Davie (2007:144) suggests that there would be two forms of the sacred likely to emerge in postmodern times: one that affirms fragmentations and another that creates islands of security. Postmodern life and society are characterised as highly uncertain and fragmented. It is implied from Davie's thesis that religious commodification is associated with fostering religious beliefs and practices which follow or affirm postmodern uncertainty and fragmentation. This is evident in new religious movements throughout Africa (that the modern has not actually authorised or taken control of), which is spawning 'new sacred signs and their profanities' (Poewe 1994:17). These involve everyday practice and human experience in changing conditions, which are often defined as turbulent, traumatic and dislocating. It opens space of belief and redefines landscape of practice in which people embrace more relevant and consumable religious messages and goods with the assistance of technologies which fit their lifestyle. So 'religious commodification, while spurring production and consumption of marketised religious goods, has unveiled some widespread trends of refashioning pieties and inspiring prosperity' (Kitiarsa 2010:564). It strongly re-affirms the 'continuing significance of religion in late modern society' (Dillon 2003:4) and thus challenges secularisation theory.

Because globalism at the core is a power concept, bearing within it asymmetrical power relations, there is no guarantee of benefit for all. Processes of globalisation value profit above people, promote economic inequality and deny our innate relatedness. It brings a relativistic homogeneity. Kalu suggests that 'the question should be posed within a new discourse designed to explore the interior dynamics and process of culture contacts in contexts of asymmetrical power relation' (2008a:9). Universal theological knowledge and educational systems from the West have 'embrace the entirety of humanity' but 'in relative, and sometimes absolute, ignorance of the majority of humankind'- that is, those living in non-Western cultures (Chakrabarty 2000:29 quoted in Kang 2014:1). There is the idea that "Western theology is normative and represents the "universal," while other theologies - African, liberation, Asian, black, feminist, are local or contextual, perspectival and limited' (Rajashekar 2015:1). It is important to challenge universal claims and the undermining of particular identities as the power relationship in the globalisation discourse, even though it allows participation, is not even. Kang affirms (2014): 
It is not, therefore, surprising to see that most resources for theological education - institutional, financial, and human with enormous means to research, archive, and disseminate knowledge, have resided in the global North, while the dire need for theological educational infrastructures and resources has drastically grown in the global South. (p. 1)

A reason for this continued dominance, Hanciles suggests, could be that 'Africa's emergence as a major centre of world Christianity is hostage to its marginalisation in the new world order - academic marginalisation being a corollary of economic insignificance' (2008:79). Bediako (2000) explains that, even before the period of colonial expansion and missionary engagement, the identity of the African was seen as that of a slave and theories of racial hierarchy relegated the African to the bottom of the scale. As it emerged in the postmissionary context of African Christianity in the late 1950s and 1960s, the question of identity entailed confronting not only the problem of 'old' and 'new' in the African religious consciousness but also how it could become integrated in a unified vision of what it meant to be Christian and African (Hastings 1979). Education was the strongest instrument employed in the missionary enterprise to domesticate or indigenise Christianity, as Antonio maintains (2006):

... why education was such a critical site of contestation during and after colonial rule: it is within education that categories of thought were formally defined and the conditions for the articulation of colonised subjects were laid down and strategies for colonised minds were deployed. (p. 19)

Bediako (1995:15) asserts, 'The issue of identity lies at the heart of the processes by which the Christian theological enterprise is carried forward'.

In the words of Priscilla Weeks (1990:236), Africa's structures of academic dependency are 'dependent on the control by the Western academy of scholarly journals and organisations through which the bulk of information is disseminated' and 'the disproportionate amount of research and development controlled by the core (i.e. Western) institutions'. Rajashekar states that 'the dominance of Western scholarship in theological literature tends to skew an authentic global engagement' (2015:6). What we find is that 'globalisation engenders new forms of hegemonic relationships that build on old structures of dominance' (Hanciles 2008:80) and is an extension of the colonial project. Justin Ukpong (2002) states:

Thus from a South Atlantic perspective, globalisation as it exists today is western imperialism in disguise, at best, a new invasion of non-Western cultures by Western power interests. (p. 29)

For Africans, then, 'it is challenging to understand or engage in dialogue when globalisation promotes the epistemological and ontological realities of the most powerful in the world' (Maweu 2011:36). In so doing globalisation has, as Maweu observes, catalysed the colonisation of African ways of knowing. To overcome this, the nature of religious experience should be viewed from several perspectives at the same time, where attention should focus on the interconnectedness of local distinctiveness and global generality. Sociologist Roland
Robertson's (1992) innovative concept of 'globalisation' is quite apt in exploring the interconnectedness between local and global contexts at the level of religious movements. This is similar to Wall's exposition of the biblical understanding of the interplay between the indigenous and pilgrim principles in Christianity (1996:53-54) or Ogbu Kalu's African Pentecostalism (2008b), which remains a comprehensive account of the role and social impact of African Pentecostal and Charismatic Christianity and an example of successfully balancing global processes with local identities. Kalu states that 'as Christianity is experienced and translated into other cultural symbols, the inculturating potential cautions against homogeneity because "hearers" interpret employing lenses sourced from their indigenous worldviews' (2008a:10). This perspective privileges the creative responses of local cultures; Kalu asserts (2008a):

By combating the blurring of boundaries and identities in the globalism discourse it become possible to demonstrate how global cultural forms are mediated in the everyday lives of ordinary people in their localities. (p. 9)

This makes room for the content of theological education to be changed, allowing the indigenous principle to bloom. It begins when theological education develops contextual approaches and hermeneutical methods based on the way African people conceive and interpret reality; Christianity based on 'spiritual worldviews, supernatural powers, preEnlightenment concepts, charismatic power, supernatural energies of the Holy Spirit and new religious movements' (Naidoo 2016). The idea is that the Church needs to become African in belief, theology and practice for it to be truly African (Bowers 2002). Bediako notes that this search actually constituted a new theological methodology, the 'hermeneutic of identity' (1992:16) based in a genuinely biblical encounter with their religious past. Hence, it will 'involve a commitment from all critical and transformative theological educators in Africa to have Africa as their focus, embracing indigenous African epistemologies in the transformation of theological discourses' (Higgs 2015:90). This is not sourced as exotic studies of 'the other' but as part of a comprehensive attempt to learn about the context in which global Christianity is thriving (Anderson 2004:11).

Thus, in working against the sameness brought about by globalisation, the dominant Western universality claim must continue to be challenged and dismantled in order to make room for other theological traditions to become included as partners in an authentic and mutual dialogue. According to Pobee (1997), doing theology with a global consciousness implies a process of building a community of communities where each has its own identity and integrity working from a fully constituted body of Christ. This work of uncovering dominant Western paradigms of knowledge is not new. However, as Andraos (2012:7) states, not enough attention is given to 'epistemic decolonization which attempts to unveil the geo-political location of theology, secular philosophy and scientific reason and simultaneously affirming the modes and principles of knowledge that have been denied the rhetoric of civilization, progress, development and market democracy'. 
For Africans it will mean asserting identity as key for a relevant theological education, as location and positionality makes a difference. But it is important to note identity as fluid and changing, because boundaries are shifting or being redefined. Those who have formerly been colonial subjects often find themselves living in the in-between or Third Space (Bhabha 1994), having to negotiate multiple realities all the time. The postmodern trajectory (Lyotard 1984), at the same time, calls into question all grand systems and meta-narratives that seek to elevate some fields or perspectives to positions of power and marginalising others. Kalu (2008a:16) has asked: 'can real exchange be possible when western intellectual assumptions deny fundamental African beliefs about God and the spirits?' How can intellectual exchange negotiate this difference? Walter Hollenweger (1997:301) pleads for a intercultural theology and education that must break out of the 'monocultural methodologies of topics of the past' that allow the theologies of the Third World to be more fully recognised and given due recognition.

\section{Implications for theological education}

Namsoon Kang (2014) provides a statement on the state of theological education. She states that:

theological education, like education in general, has played two roles: firstly as a mere reproducer of existing reality and secondly theological education has also been a visionary challenger of the status quo that requires a prophetic criticism of the world to create the possibility for an alternative reality. For the latter to happen, theological educators need to construct new models for theological education by engaging the universals of justice, equality, freedom, and human rights in an uneven world today. (p. 1)

Within theological education, this will involve a fundamental re-imagining of theological discourse, curriculum, pedagogy and institutional systems to create humanising education rather than consuming packages with the intent to conquer the world of the Christian marketplace. Thislethwaite and Cairns (1994:10) suggest that we need to develop a 'theological anthropology that takes account of differences in concrete social locations for the transaction of becoming human in the process of transforming the world'. For example, envisioning theological education as formational based on the assumption that the student's personal appropriation of theology is a key aspect of theological education (Foster 2006) with a holistic focus can counteract commodification. The scope of education must go beyond a restrictive cognitive qualification to more integrated human development. This formational notion of theological education is what Farley (1984) labels as theologia, rather than theology, in order to underline that it is a kind of personal wisdom, a way of being human.

In addition there should be humane teaching-learning communities with a commitment to and practice of dialogical relationality. Real conversation is required for true community but it occurs only when the community is willing to be vulnerable in examining its situatedness in careful and boundaried ways. Building community requires positive, affirming and responsible relationships among its participants. If theological institutions do not model and practice a new form of community, they will have no credibility when speaking to the world. Thus, the way education occurs is as important as its content.

It is entirely possible that Christianity in the West may have overemphasised formal education. This in turn has produced curricula insensitive to the contextual needs of Africa, curricula that produce decontextualised thinkers and theologians (Gustafson 1988). Theological education must involve training and equipping pastoral leaders to do theology by involvement at the grassroots level and developing responsiveness to that level. Rather informal and non-formal theological education is seen as the most effective for the African context because it is appropriate to the life of the community (Erny 1981; Irele 1992), involves vernacular materials and accesses oral traditions. Anderson (2004) agrees and suggests that:

if more recognition or accreditation were given to the experiences of ministry and the developing spirituality that these experiences bring, we would be educating people in Pentecostal/Charismatic spirituality more effectively. We must find ways to quantify and realise this, and to integrate cognitive learning with concrete, active learning. (p. 10)

In addition, theological educators' mode of seeing and reading the world needs to becomes transformed, not merely in the construction of new theological discourses but also in the radical transformation of the concrete implementation of the discourse in the praxis of theological institutions (Kwok 2014:2). For example, the homogenous make up of institutions in terms of race, gender and class challenges the emergence of a counter-paradigm.

\section{Conclusion}

The intensification of the globalisation process in recent years has forced us to rethink our engagement with this reality. Globalisation can be seen as the church's universal mission to evangelise, support ecumenical cooperation and the human development of millions. It has opened up untold fresh possibilities for theology and vastly multiplied resources in theological education. On the other hand, globalisation reinforces existing patterns of cultural colonisation, social, political and theological exclusion in institutions and their curricula resulting in consuming patterns.

Globalisation in its present hegemonic form needs to be 'interrupted', not only with prophetic words but also with courageous actions that enhance a more even playing field. Theological education in a global context will involve the need to dialogue and work with theologies and scholarship from diverse context and experiences. The challenge is whether collaborative efforts can be developed with the West so that participation can be meaningful without diluting African identity. 


\section{Acknowledgements Competing interests}

The author declares that he has no financial or personal relationships which may have inappropriately influenced him in writing this article.

\section{References}

Anderson, A., 2004, 'Pentecostal-Charismatic spirituality and theological education in Europe from a global perspective', PentecoStudies 3(1), 1-15.

Andraos, M.E., 2012, 'Engaging diversity in teaching religion and theology: An intercultural, de-colonial epistemic perspective', Teaching Theology and Religion 15(1), 3-15. https://doi.org/10.1111/j.1467-9647.2011.00755.x

Antonio, E.P., 2006, Inculturation and postcolonial discourse in African theology, Peter Lang, New York.

Balia, D.M. \& Kim, K., 2010, Witnessing to Christ today, Regum, Oxford.

Bhabha, H. K., 1994, The location of culture, Routledge, London.

Bauman, Z., 2008, Does ethics have a chance in a world of consumers? Harvard University Press, Cambridge, MA.

Bediako, K., 1992, Theology and identity: The impact of culture upon Christian thought in the second century and modern Africa, Regnum Books, Oxford.

Bediako, K., 1995, Christianity in Africa, Orbis Books, Maryknoll. NY.

Bediako, K., 2000, 'A half century of African Christian thought pointers to theology and theological education in the next half century', Journal of African Christian Thought 3(1), 5-11.

Bellah, R.N., 1970, Beyond belief: Essays on religion in a post-traditional world, Harper and Row, New York.

Berger, P.L., 1997, 'Four faces of global culture', The National Interest 49(Fall), 23-29.

Bird, D.L. \& Smith, S.G., 2009, Theology and religious studies in higher education: Global perspectives, Continuum, London.

Bosch, D., 1991, 'The nature of theological education', Journal of Theology for Southern Africa 77, 3-17.

Bridges, D. \& Jonathan, R., 2003, 'Education in the market', in N. Blake, P, Smeyers, R. Smith, \& P. Standish (eds.), The Blackwell guide to the philosophy of education, pp. 126-145, Blackwell Publishing, Oxford, UK.

Bowers, P., 2002, 'African theology. Its history, dynamics, scope and future', African Journal of Evangelical Theology 21(2), 109-125.

Carpenter, J., 2008, 'New Evangelical Universities: Cogs in a world system or players in a new game?', in O.U. Kalu \& A.M. Low (eds.), Interpreting contemporary Christianity: Global processes and local identities, pp. 151-186, Eerdmans, Grand Rapids, MI.

Chakrabarty, D., 2000, Provincializing Europe: Postcolonial thought and historical difference, Princeton University Press, Princeton, NJ.

Conradie, E.M., 2011, 'Knowledge for sale? The impact of a consumerist hermeneutics on learning habits and teaching practices in higher education', Koers 76(3), 423-446. https://doi.org/10.4102/koers.v76i3.36

Davie, G., 2007, The sociology of religion, Sage, London.

Dillon, M., 2003, 'The sociology of religion in late modernity', in M. Dillon (ed.), Handbook of the sociology of religion, pp. 3-15, Cambridge University Press, Cambridge.

Dunsmuir, C. \& McCoy, M., 2015, 'Accreditation and ministerial formation. Serving two masters?', in M. Naidoo (ed.), Contested issues in training ministers in South Africa, pp. 38-53, Sun Media, Stellenbosch.

Dyrness, W.A., 2014, "Why don't we hear much from the Global Church?" Teaching theology in a global and transnational world', viewed 15 March 2017, from http:// teachingtheology.blogspot.com/2011/11/why-dont-we-hear-much-from-global. html

Erny, P., 1981, The child and his environment in black Africa, an essay on traditional education, Oxford University Press, Nairobi.

Farley, E., 1984, Theologia: The fragmentation and unity of theological education Wipf and Stock Publishers, Eugene, OR.

Foster, C.R., Dahill, E.L., Golemon, L.A. \& Tolentino, B.W., 2006, Educating clergy: Teaching practices and pastoral imaginations, Jossey Bass, San Francisco, CA.

Gustafson, J.M., 1988, 'Reflections on the literature on theological education published between 1955 and 1985', Theological Education Supplement 2(24), 9-88.

Glifford, P., 1998, African Christianity: Its public role, Indiana University Press, Bloomington, IN.

Hanciles, J.J., 2008, 'African Christianity, globalization and mission: Marginalizing the center', in O.U. Kalu \& A.M. Low, Interpreting contemporary Christianity: Global processes and local identities, pp. 71-92, Eerdmans, Grand Rapids, MI.

Hastings, A., 1979, A history of Christianity in Africa 1950-1975, Cambridge University Press, Cambridge.

Hellas, P., Woodhead, L., Seel, B., Szerszynski, B. \& Tusting. K., 2005, The spiritual revolution: Why religion is giving way to spirituality, Wiley-Blackwell, London.
Higgs, P., 2015, 'The African renaissance and the decolonisation of theological education', in M. Naidoo (ed.), Contested issues in training ministers in South Africa, pp. 86-98, Sun Media, Stellenbosch.

Hollenweger, W., 1997, Pentecostalism: Origins and developments worldwide, Hendrickson, Peabody, MA.

Hueser, A. (ed.), 2015, Pastures of plenty: Tracing religio-scapes of prosperity Gospel in Africa and beyond, Peter Lang, Frankfurt.

Irele, A., 1992, African education and identity, Spectrum Books, Ibadan.

Jenkins, P., 2002, The next Christendom: The coming of global Christendom: The coming of global Christianity, Oxford University Press, New York.

Johnson, T.M. \& Ross, K.R., 2009, Atlas of global Christianity, University Press, Edinburgh.

Kalu, O. U., 2006, 'Multicultural theological education in a non-western context: Africa, 1975-2000', in D.V. Esterline \& O.U. Kalu (eds.), Shaping beloved community: Multicultural theological education, pp. 225-242, Westminster John Knox Press, Louisville, KY.

Kalu, O.U., 2008a, 'Changing tides: Some currents in world Christianity at the opening of the twenty-first century', in O.U. Kalu \& A.M. Low (eds.), Interpreting contemporary Christianity: Global processes and local identities, pp. 151-186, contemporary Christianity: Globans, Grand Rapids, MI.

Kalu, O.U., 2008b, African Pentecostalism: An introduction, Oxford University Press, Cary, NC.

Kang, N., 2014. 'Radical border-traversing: Theological education in a glocalized world of disjuncture', viewed 15 March 2017, from https://www.aarweb.org/ node/1868

Klein, N., 1999, No logo: Taking aim at the brand bullies, Picador, New York.

Kitiarsa, P., 2010, 'Toward a sociology of religious commodification in Turner', in B.S. Turner (ed.), The new Blackwell companion to the sociology of religion, pp. 563-583, Wiley-Blackwell, Oxford.

Kwok, P., 2014, Teaching theology in a global and transnational world, viewed on 20 March 2017, from https://www.aarweb.org/publications/spotlight-ontheological-education-march-2014-teaching-theology-in-a-global-andtransnational-world

Levy, D., 2007, 'A recent echo. African private higher education in an international perspective', Journal of Higher Education in Africa 5, 197-220.

Lyotard, J.F., 1984, The postmodern condition: A report on knowledge, Manchester University Press, Manchester.

Maweu, J.M., 2011, 'Indigenous ecological knowledge and modern western ecologica knowledge. Complimentary, not contradictory', Thought and Practice. A Journal of the Philosophical Association of Kenya 3(2), 35-47.

McKinney, L.J., 2003, 'Evangelical theological education: Implementing our own agenda', viewed 20 March 2017, from http://www.icete-edu.org/pdf/0\%20 03\%20McKinney\%200ur\%200wn\%20Agenda.pdf

Miller, V.J., 2003, Consuming religion: Christian faith and practice in a consumer culture, Continuum, New York.

Moodie, T., 2008, 'TEE College of South Africa', in R. Kinsler (ed.), Diversified theological education. Equipping all God's people, pp. 47-80, William Carey International University, Pasenda.

Moore, R.L., 1994, Selling God: American religion in the marketplace of culture, Oxford University Press, New York.

Naidoo, M., 2012, 'Ministerial formation of theological students through distance education', HTS Theological Studies 68, 1-8. https://doi.org/10.4102/hts. v68i2.1225

Naidoo, M. (ed.), 2015, Between the real and the ideal: Ministerial formation in South Africa Churches, Unisa Press, Pretoria.

Naidoo, M., 2016, 'Overcoming alienation in Africanising theological education', HTS Theological Studies 71(3), 1-7. https://doi.org/10.4102/hts.v72i1.3062

Overend, P., 2007, 'Education or formation: The issue of personhood in learning for ministry', Journal of Adult Theological Education 4(2), 133-148. https://doi. org/10.1558/jate2007v4i2.133

PEW Forum on Religion and Public Life, 2010, Islam and Christianity in sub-Saharan Africa, viewed 10 March 2017, from http://www.pewforum.org/2010/04/15/ executive-summary-islam-and-christianity-in-sub-saharan-africa/

Pobee, J., 1997, Towards viable theological education, WCC Publications, Geneva.

Poewe, K. (ed.), 1994, Charismatic Christianity as a global culture, University of South Carolina Press, Colombia.

Rajashekar, J.P., 2015, 'Theological education in an era of globalization', Journal of Lutheran Ethics, viewed 10 March 2017, from https://www.elca.org/JLE/ Articles/1069

Ritzer, G., 1996, The McDonaldization of society (ed.), Pine Forge Press, Thousand Oaks, CA.

Robertson, R., 1992, Social theory and global culture, Sage, London.

Sandel, M.J., 2012, What money can't buy: The moral limits of markets, Farrar, Straus, and Giroux, New York.

Thislethwaite, S.B. \& Cairns, G.F. (eds.), 1994, Beyond theological tourism: Mentoring as a grassroots approach to theological education, Orbis Books, New York.

Ukpong, J., 1995, 'What is contextualizaton', in T. Norman (ed.), Readings in world mission, pp. 56-70, SPCK, London,. 
Ukpong, J., 2002, Reading the Bible in a global village: Cape Town, Brill, Leiden.

Van der Water, D.P., 2005, 'Transforming theological education and ministerial formation', International Review of Mission 94(373), 203-211. https://doi. org/10.1111/j.1758-6631.2005.tb00495.x

Walls, A.F., 1996, The missionary movement in Christian history, Orbis Books, Maryknoll, NY'

Walls, A.F., 2000, 'Of Ivory Towers and Ashrams some reflections on theological scholarship in Africa', Journal of African Christian Thought 3(1), 1-2.

Wallerstein, I., 1974, The modern world system, Academic Press, New York.

Warner, R., 2011, 'How congregations are becoming customers', in G. Redden \& M. Bailey (eds.), Mediating faiths: Religion and socio-cultural change in the twenty-first century, Ashgate, Surrey.
Ward, G., 2006, 'The future of religion', Journal of the American Academy of Religion 74(1), 179-186. https://doi.org/10.1093/jaarel/Ifj024

Waghid, Y., 2001, 'Globalisation and higher education restructuring in South Africa: Is democracy under threat?', Journal of Education Policy 16(5), 455-464. https:// doi.org/10.1080/02680930110071048

Werner, D., 2009, Challenges and opportunities in theological education in the 21st century, Bossey Ecumenical Institute (ETE/WCC), Geneva.

Weeks, P., 1990, 'Post-colonial challenges to grand theory', Human Organization 49(3), 236-244. https://doi.org/10.17730/humo.49.3.11514802t2424223

Wilton, G., 2007, 'The Hind Report: Theological education and cross sector partnerships', Discourse: Teaching and Learning in Philosophical and Religious Studies 7(1), 153-178. 